\title{
CORPUS TOPONYMICUM SLOVACIAE MEDIEVALIS (CTSM) - ON-LINE DATABASE OF MEDIEVAL TOPONYMIC MATERIAL AND ITS APPLICATION IN ONAMASTIC AND LINGUISTIC RESEARCH
}

\author{
Peter Labanc
}

DOI: 10.17846/CL.2019.12.1.22-38

\begin{abstract}
LABANC, Peter. Corpus Toponymicum Slovaciae Medievalis (CTSM) - On-line database of medieval toponymic material and its application in onamastic and linguistic research. Identification of localities mentioned in historical sources is one of the basic components of medieval historians' daily work. Different types of publications can be exploited in this practice. Above all, specialized gazetteers and works aimed at settlement reconstruction belong to them. However, there does not exist a tool which would cover the whole territory of the medieval Hungarian kingdom and within it the territory of the present day Slovakia. Furthermore, this group of publications lacks uniformity and unification. As a result, the effective localization of the objects is difficult and slow. The paper presents the basic principles of the CTSM database (toponymica.sk) functioning and its system of populating, because the CTSM has the ambition to resolve the outlined fragmentation of gazetteers. The paper also shows the possibilities of its application in other scientific disciplines, especially in linguistics and onomastics.
\end{abstract}

Keywords: Medieval Toponymy, on-line database; Gazetteer; Onomastics; Linguistics

\begin{abstract}
Abstrakt: LABANC, Peter. Corpus Toponymicum Slovaciae Medievalis (CTSM) - elektronická databáza stredovekého toponymického materiálu a jej využitie v onomastickom a lingvistickom výskume. Jednou zo základných činností historika-medievistu pri každodennej práci je identifikácia lokalít spomínaných $\mathrm{v}$ študovaných prameňoch. Pri tejto činnosti sa dajú využit publikácie rôzneho charakteru. Patria medzi ne predovšetkým špecializované zemepisné slovníky a práce zaoberajúce sa rekonštrukciou osídlenia. Neexistuje však žiadny nástroj pokrývajúci celé územie stredovekého Uhorského královstva, resp. územie Slovenska. Navyše ani tie existujúce nie sú unifikované. Tieto skutočnosti komplikujú efektívnu identifikáciu terénnych názvov v priestore. Predložená štúdia predstavuje základné princípy fungovania a napĺñania databázy CTSM (toponymica.sk), ktorá má ambíciu vyriešit roztrieštenosti historicko-zemepisných príručiek. Na viacerých konkrétnych prípadoch zároveň ukazuje možnosti jej využitia v dalších vedných disciplínach, predovšetkým v lingvistických a onomastických výskumoch.
\end{abstract}

Klúčové slová: stredoveká toponymia, on-line databáza, miestopisný slovník, onomastika, jazykoveda

One of the important elements of a more in-depth study of history, and the professional training of an historian-to-be, is the sense of geography of historical processes. This primary interconnection of history and geography is merely a foundation on which promising research can be built. In any case, no historian is able to avoid localisation of the investigated events. It is a key 
and irreplaceable part of the heuristic phase which the historian carries out by means of source editing, followed by archival research. During these tasks it is necessary to select sources according to a certain key, depending on the chosen subject. One of them may be a geographic criterion, mainly used for settlement research or specific issues explored within a narrower geographical scope. From the overall perspective, this type of selection is mostly used in the preparation and publication of the national Codex Diplomaticus and Regesta, which notably appear in the 19th century. ${ }^{1}$

The concept of the regional/territorially based Codex Diplomaticus presumes publishing all of the documents concerning defined territory. ${ }^{2}$ From the point of view of all the former parts of the Kingdom of Hungary (unified also by a personal union), applying this criterion means performing heuristics of archival material mainly in the most important archive for medieval Hungary Magyar Nemzeti Levéltár in Budapest. Here more than 108000 documents and a similar number of photographic copies of documents relating to the history of the Kingdom of Hungary are held in a separate collection Diplomatikai Fényképgyüjtemény (more than 94000 items). Altogether, these original sources and photocopies contain the text of almost 300000 medieval documents and letters (Rácz 2010, 423-425).

Beyond the basic training of an historian, which includes the ability to handle such material, the key point in the territorially defined heuristics is the ability to localise the geographic proper names found in specific documents. On a theoretical level, it could be based on a binary response question: 0 - does not apply to the territory of Slovakia, 1 - does apply to the territory of Slovakia. However, such exactness is not known to historical research. It is not only complicated by the existence of the documents whose reference to Slovakia is only assumed, but especially by cases where, without further research, it is impossible to determine whether it indeed is a locality on Slovakian territory.

From the source editor's point of view, the ideal situation would be to enter such heuristics equipped with the tool that would enable as many unambiguous answers as possible in the $0-1$ system, thus minimising ambiguous examples. If welook at this issue through the eyes of the designer of this handbook, ideally he would like to rely on the source editions that systematically cover written material. From these deliberations one basic statement arises: that the source heuristics (or editorial work) and designing of the tools for localising geographical names are communicating vessels and cannot be separated. However, the localiser of the geographical names should be a few steps ahead. If we were to peek into the workshop of Prof. V. Sedlák, perhaps the most famous historian in the onomastics circles, there we would find several laboriously created tools designed specifically for identification and classification of geographical names in the medieval written material. We can appreciate their functionality, and importance, while browsing through Vlastivedný slovník obcí na Slovensku (VSO I - III, 1977 - 1978) \{Gazetteer of the Slovak Villages\}. For this work, V. Sedlák produced a summary of historical names for each locality (I.1. part of the entry). In the past few decades, the situation has changed only partially, and to this day, there is still no comprehensive historical gazetteer covering the entire territory of medieval Slovakia or the Kingdom of Hungary. The historian must therefore reach out for various works, which differ

In Slovakia the systematic work in source editing for the earliest period (CDS1 I 1971; CDS1 II 1987; RDS1 I 1980; RDS1 II 1987) only began in the 1950s (Sedlák 2003, 9). To this day, two volumes of each work were published, covering source material relating to Slovak history up to the year 1260 (CDSl I 1971; CDSl II 1987) and years 1301 - 1323 (RDSI I 1980; RDSI II 1987). They both are of an invaluable significance in the research of a particular period and set the criteria for scientific source editing to a high level.

2 In the case of Slovakia it was defined to territory and inhabitants of Slovakia (Marsina 1957, 300). 
not only in their geographical restrictions, but also in their chronological extent, the structure of entries, research methodology and the breadth of heuristic.

Besides earlier works, D. Csánki's intention of creating a historical topography of the Kingdom of Hungary during the Hunyadi dynasty began to be realised. This, however, failed to cover mainly the western part of today's Slovakia: Bratislava, Nitra, Ostrihom, Tekov, Turiec, Orava, Liptov, Zvolen and Hont counties (Csánki - Fekete-Nagy 1890 - 1941). ${ }^{3}$ The gaps of Csánki’s topography were supposed to be filled in and bridged by the editorial work based on new foundations under the guidance of an important Hungarian medievalist Gy. Györffy. The first volume of the Historical Topography of the Kingdom of Hungary during the Arpad dynasty was published in 1963, which despite its name processed the material up to the 1330s. ${ }^{4}$ Two more volumes followed in 1987, and the fourth, so far the last part, was published in 1998 (Györffy 1963 - 1998). ${ }^{5}$ The work is again structured on the basis of counties in alphabetical order by their Hungarian names. In the first volume are included the Slovakian regions of Abov, Orava (Hun. Árva) and Tekov (Hun. Bars) counties; in the second it is Ostrihom (Hun. Esztergom), Gemer and Ráb (Hun. Györ); in the third it is Hont and Komárno and finally, in the fourth it is Liptov, Mošon, Novohrad and Nitra counties. Even the combination of Csánki and Györffy's topography does not guarantee coverage of the entire territory of Slovakia because they do not include gazetteers of Bratislava, Turiec and Zvolen counties. In many cases even Csánki's work is not sufficient. That is why historians have to reach out for works that do not have an explicitly topographical character, but they offer a large amount of material.

From the Hungarian works, A. Fekete-Nagy's book on Spiš from 1934 (Fekete-Nagy 1934 ) is worth mentioning in particular. This work is valuable especially from the perspective of the author's vast heuristics. The Bratislava County Topography by J. Házi (2000) has the character of the gazetteer. Two works were published for the region of Turiec: the first thanks to E. Mályusz in 1922 (Mályusz 1922) and later in 1996 J. Beňko added his authorial achievement (Beňko 1996). The author indirectly followed on from his book on the settlement of northern Slovakia, where he focused on the northern parts of Trenčín, Liptov, Spiš, Šariš and Zemplín counties and the entire Orava county (Beňko 1985). For Liptov, it is worth mentioning the work of A. Húščava (1930) based methodologically on the publication of his teacher V. Chaloupecký (1923), around which a more emotive and stimulating discussion sparked up thanks to D. Rapant (1934).

Furthermore, in 1980s the three part work of F. Uličný on the settlement of Liptov in the Middle Ages was published (Uličný 1983, 1985, 1987). The neighbouring county of Orava lived to see its own topography thanks to A. Kavuljak (1955). The dissertation work of M. Mrekaj is also worth a mention, although it has not seen the light of day in its book form yet (Mrekaj 2012). Of similar nature is a monograph by P. Maliniak dedicated to Zvolen County (Maliniak 2009).

A valuable source of facts is provided by the topography of the settlement of three eastern Slovakian counties (Šariš, Zemplín, Užhorod) by the aforementioned F. Uličný (Uličný 1990, 1995, 2001). Different approaches were chosen by V. Rábik who studied the German settlement of Šariš, Abov, Zemplín and Užhorod counties, (Rábik 2006); and M. Marek, who analysed the distribution

3 The first volume included counties that were completely or partially overlapping the territory of Slovakia: Novohrad, Gemer, Abov, Turiec, Spiš, Šariš, Zemplín and Už. In the third volume it was Komárno, Ráb and Mošon. The fourth volume by A. Fekete-Nagy is concerned solely with the Trenčín County. The second and fifth volumes do not contain Slovakian counties. A register for this work was published in 2002 (Ördög 2002).

4 Formally the time limit is defined by the date of completion of the papal tithes register, which was created between the years 1332 - 1337 (MVSl I 2008, 13-17, MVH I/1 1887 19-409).

5 The first volume was published in a new edition in 1987 along with two others. 
of individual ethnic groups across the settlement of medieval Slovakia (Marek 2006). For eastern Slovakia, it is impossible to overlook B. Varsik and his monumental tripartite work The Settlement of the Košice Basin (Varsik 1964 - 1977).

By no means does the submitted list claim to be complete. The listing of literature that is relevant and essential for spatial identification of locations could go on for a long time. The aim of this selection was mainly to point out several differences. First of all, they are works created in different periods of time, which are subject to technical limitations of earlier works. The second notable difference is the chosen method and the formulation of the analysis results. Many of these works are not topographies in the true sense of the word, even though they partly perform such a role. It is also possible to find their common ground, which is their focus mainly on the settlements. However, little emphasis is placed on the research of other topographical names. Historians pay attention mostly to the names of watercourses - hydronymy. Other toponyms are used and explored only sporadically. In addition, there is one more practical problem, which Prof. V. Sedlák tried to solve in his working card index. All the works classify the material according to counties, thus impeding the possibility of a broad geographical search and more efficient identification of a particular name type.

This briefly outlines how the idea of creating the corpus of medieval toponymic material for the territory of Slovakia was born. The primary motivation was the need for a handbook for spatial identification of the locations. Given the huge amount of preserved material (tens of thousands of sources for the territory of Slovakia alone) and the support (or not) of basic research in humanities (and related issue of an insufficiently broad team), the conventional way (printed handbook) is almost unfeasible. The relevance or the need for such approach is, in this day and age, questionable, as the digital form of a freely available on-line database with wide search capabilities offers much greater convenience, not only for historians, but also for scientists in other disciplines. In addition, it eliminates various constraints of previous approaches - the time horizon for the publication of the results, the (im-) possibility of updating or corrections, mobility and accessibility of the database, etc.

\section{Creating a record in the CTSM database}

The basis of the Corpus Toponymicum Slovakia Medievalis database (CTSM) is a record containing several basic data. Their selection and structure stems primarily from the need of an historian, but they are created with their applicability to other disciplines in mind, e. g. in onomastics and linguistics.

ID: Each inserted database record will automatically be assigned its individual unique identification number. This data will be crucial when referring to a source in academic works. The advantage of a simple $6-7$ digit number will also be appreciated by those who want to look up the quoted source retrospectively without typing or copying a long URL address (e. g. http:// toponymica.sk/14).

Toponym: The core data in the database is the toponym in its exact (transliterated) form taken directly from the source. What could prove problematic are not only the names with alternative readings, which can be solved by the adding of all variants, but potentially identical graphical form of the graphemes $t$ and $c$. The solution will be setting the search so that both of them will be searched for while searching for one of these graphemes. If we enter the name 'Geche', the potential search results will be the terms 'Geche' and 'Gethe' (were they to be in the database). 
It is worth adding that this data will be beneficial not only for the period of the 14th and 15th centuries, when the number of sources starts to grow, but they will also play a role in revising erroneous readings of the toponyms in earlier editions, which has often led to misinterpretations, also in e. g. V. Šmilauer's Hydrography (Šmilauer, 1932).

Today's name: Filling in this field depends on whether we can identify the toponym with the one of the present day. This is easier for continuously inhabited locations or more significant waterways or hills. Identification is often facilitated by its specification in the source itself. A source from 1371 may be used as an example. It mentions fluvium Zekpataka nuncupatum per possessionem Leton defluentem (MNL OL DF 272 397). Due to the historical position of Letanovce, it is a stream running past the local church and flowing into Brusník. However, assigning the value 'today's name' is complicated by the fact that this watercourse does not have a standardized name, ${ }^{6}$

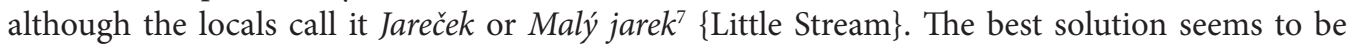
to draw the user's attention to the non-standardized form of its name.

Toponyms of no longer existing historical objects, e. g. abandoned settlements, make up a separate group. The literature often uses a reconstruction approach to such toponyms (with variable suitability). Sometimes the preserved topographical name is used (e. g. Margecianka pri Studenci, Levoča dist. $)^{8}$, in some cases historians choose an artificial name (e. g. ${ }^{\star}$ Štefkovce, abandoned medieval village near Nemešany, Levoča dist.). ${ }^{9}$ These reconstructions have mainly a distinguishing function, as in many cases common ways of naming settlements are used. If we remain with the aforementioned Margecianka, there are two other sites in the Spiš area bearing the name of the patron saint of the local church: Margecany (Gelnica dist., first written record of the village is from 1328 - MNL OL DL 83 199: ... villis sancti Anthonii et sancte Margarethe...) and Margoričany (topographical name in the bounds of Vel'ká Lesná, Stará Lubovňa dist. on the way to Toporec, first written record is from 1323 - MNL OL DL 63 648: ... Scenmargita...).

The data in this field will have three variants: (1) today's standardized name, (2) a reconstructed name (using an existing topographical name or artificially created one), and (3) a blank field.

Location type: This field is used mainly for specification in more detailed research focusing on one type of object. Selection options will be limited. Eight basic categories were selected from a trial sample of approximately 7000 medieval toponyms obtained from the research of the original archival material: ${ }^{10}$

- Settlement - this is the most represented category. It includes towns, small towns, villages or smaller farmsteads. E. g. civitas murata Podolyn (MNL OL DL 9 432); opidum Zepsy (MNL

6 A list of standardized watercourses names to February 2017 [cit. 2019-01-24]. Available on the Internet: http://www.skgeodesy.sk/files/slovensky/ugkk/geodezia-kartografia/standardizacia-geografickehonazvoslovia/nazvy-vod/vodne-toky_februar_2017.pdf.

7 I would like to thank doc. PhDr. Michal Slivka, PhD. ( ${ }^{*} 1948$ Letanovce) for this information.

8 Objects catalogue ZB GIS [cit. 2019-01-24]. Available on the Internet: https://zbgis.skgeodesy.sk/mkzbgi $\mathrm{s} /$ ?bm $=\mathrm{zbgis} \& \mathrm{z}=15 \& \mathrm{c}=20.75087,49.05516 \# /$ detail/ease/AV8VS6id9GWJhBSWqW_K.

9 Belo Polla (1962) carried out archaeological investigation of the site under its different name. It is found in the sources under the names: 1295 Villa Stephani (MNL OL DL 63 621); 1319 Stepkfalua (RDSl II, 1987, 205, No. 434); 1343 Villa Stephk (MNL OL DL 83 237). To locate it see Števík (2006, 103-108); Slivka (2010, 51-52, note no. 32); Števík (2011, 99-101); Labanc (2011, 178-179); Labanc (2013, 84-85). The discussion brought about a revision of localisation published by Fekete-Nagy (1934, 157-158).

${ }_{10}$ For help with the initial testing of the database working version, I would like to thank the students of the Department of History of the Faculty of Arts of the University of Trnava who in 2016 and 2018 attended a course led by me entitled Seminar on Slovak Medieval History. 
OL DL 8 269); Villa Montis Sancti Georgii (MNL OL DF 266 933); villicula vulgariter Heg dicta (MNL OL DL 63 668); possessio Aranyas (MNL OL DL 272 618); predium Kromlaw (MNL OL DL 21 197).

- Watercourse/spring/body of water (hydronyms) - a very large group, because in the Middle Ages watercourses used to be one of the main landmarks. E. g. fluvius Turuch (MNL OL DL 65 737); rivulus Kostrochinpataka (MNL OL DL 74 878); fons Belahozthe (Marek 2013, 355-356, No. 246); lacus Sarhegh (Marek 2010, 155-158, No. 150); gurges Trebogoch (Marek 2010, 155158, No. 150); rivulus Eisseyfen alio nomine Brusnik (MNL OL DL 74 864).

- Land/estate/territory - a relatively broadly represented group of different toponyms designating a certain area. E. g. districtus Challokuz (MNL OL DL 2889); confinium Morauie (CDSl II 1987, 81-82, No. 124); locus Maliscapotoca (MNL OL DL 45); Lyptovya (MNL OL DL 65 737); comitatus Sarus (MNL OL DL 64 136); terra non arabili qua dicitur Drysch (MNL OL DL 74 864); particle terre versus silvam Nigram, que vulgariter fovea carbonum appellatur (RDS1 II 1987, 357-358, No. 814) and others.

- Building/structure - the less represented this category is in the overall corpus, the more important it is in the reconstruction of historical processes, especially in the field of economy or everyday life research. It is also necessary to include in this category names of sacral structures, although they are not toponyms in the true sense. This will create a basic database for a comprehensive list of medieval dedication to a patron saint and ecclesiastical topography, the absence of which is noticeable. E. g. pons Tyryk (SASK Scr 9, f 1, No.20); molendinum Turkmolma (MNL OL DL 40 492); obstacula Weer (MNL OL DF 266 829); curia Hank Mayur vocata (MNL OL DL 39 674); fodina lapidum vulgariter Kuzuruku nominatam (MNL OL DL 64 644); Montana Vrbura (MNL OL DL 63 773); argenti fodina Seyler vocata (MNL OL DL 83 268); ecclesia beate Marie Virginis in Schevnek (MNL OL DF 263 199).

- Mountain/hill/rock/mountain range - this is also a popular landmark for delimitation of estates, surely thanks to its stability and relative permanency. In this group, there are not only larger geomorphological units, but also smaller rock formations. E. g. montes Symina et alpes Tarchal (MNL OL DL 63 684); mons niger dictus vulgariter Swarczenberg alio nomine Feketeerdew (MNL OL DL 74 864); lapis Iestrabskala (MNL OL DF 272 423); petra Scalka (MNL OL DL 74 878); monticulus Pachys (MNL OL DL 63 810); monticulus, qui vulgo Holum dicitur (RDSl II 1987, 195-196, No. 410) etc.

- Field/forest/meadow/vineyard/orchard - the number of these names grows in direct proportion with the economic use of the landscape. The forest used to be one of the basic sources of raw material and each town and village took care of it accordingly, or they strongly defended their interests in the event of outside interference. Sources from the later period (after 1400) mention the forest quality characteristics more often - commercially used forest, protected forest (grove), young forest, coppice, etc. E. g. pratum Toplica (RDSI II 1987, 99-100, No. 185); silva Slauci Frydpusch (MNL OL DF 266 937); silva vetita vulgariter Ereztuen vocata (MNL OL DL 39 674); nemus Liznicza (MNL OL DL 60 959) etc.

- Route/road/path - the overwhelming majority of references to any route does not contain any information about its name. Usually, they are given a common attribute (usually magna), alternatively they have a specified direction - where from and where to do they lead. E. g. ... viam, qua itur versus Hungariam... (MNL OL DL 39 635); ... magnam viam, qua itur de Sancto Georgio... (MNL OL DL 40 246); ... magnam viam predictam, per quam itur ad ecclesiam beati Martini de Almas... (MNL OL DF 272 247). Although the proper name itself is rare, in any case, it does occasionally appear in the sources. E. g. via Kwhydwtha (MNL OL DL 13 369), via exploratorum de Bohemia, que vulgo dicitur Symaruth (CDSl II 1987, 367-368, No. 532) etc. 
- Part of the settlement/town quarter/street - part of the settlement, especially the streets or quarters, should be considered as a specific category. Their names are more frequent in the sources from the 15th century onwards. They are a very important source of the town's topography, its economic life as well as its ethnic structure. E. g. parts of the town Bardejov in the source from 1425: antiqua platea, in der Rewfer gasse, Foris civitatem, In Longa linea, Platea Sclavorum, In suburbio, Ultra aquam, In platea Lutifigulorum, In secunda linea Lutifigulorum, In platea Hospitalis, In platea Hilpisch, In secunda linea (ZsO XII 2013, 351-361, No. 911).

Of course, we have to take into consideration the toponyms that cannot be included in any of the listed categories. Therefore, the category 'Other' will be created. Out of this one, in time, a new group may be selected when it reaches a relevant number of entries.

Source issue date: The importance of this information is obvious not only to historians. It allows synchronous and asynchronous data comparison. Due to a huge amount of material and the populating capacity of the database, this field will be limited to a year or a period in which the source containing the analysed toponym was created. This only applies to the originals. For later name forms (B, C, D, E, F, M, P, R, T) the database will contain time data in sequence, up until the original name form. Although this information is included in e. g. arpadian topography (Györffy, 1963-1998), some works do not pay sufficient attention to it despite the fact that its contribution to the toponym entry form is vital. Neither Slovak methodology of hydronymy editions (Krško 2005, 15-39) nor the publications mapping individual river basins of Slovak rivers (selectively e. g. Majtán - Rymut 2006; Hladký 2011; Závodný 2012; Goótšová - Chomová - Krško 2014, Beláková 2014) place much importance on this information. If the source has been copied multiple times, it can result in either:

- non-significant change of the graphemes without affecting entry comprehension,

- (intentional or unintentional) erroneous copying of the original toponym, for example as a result of updating the historical record depending on the period when copy was made (intentional) or as a result of incorrect reading (unintentional).

An example of the first case is the document from the Spiš Chapter House from 7th December 1279 , containing agreement on the settlement of the area under the High Tatras, which has been preserved not only in its original (A), but also in a number of authentic medieval copies (C).

\begin{tabular}{|c|c|c|c|c|c|c|c|c|c|c|}
\hline Form & Year & & Year & & Year & & Year & Year & Entry & MNL OL DL \\
\hline A & 1279 & & & & & & & & Cethana & 74779 \\
\hline $\mathrm{C} 1$ & 1279 & $>$ & 1292 & $>$ & 1308 & & & & Cethana & 74782 \\
\hline $\mathrm{C} 2$ & 1279 & $>$ & 1292 & $>$ & 1308 & $>$ & 1331 & & Cethana & 74792 \\
\hline C3 & 1279 & $>$ & 1292 & $>$ & 1308 & $>$ & 1348 & & Cetana & 74809 \\
\hline $\mathrm{C} 4$ & 1279 & $>$ & 1292 & $>$ & 1308 & $>$ & 1348 & & Chetene & 74811 \\
\hline C5 & 1279 & $>$ & 1292 & $>$ & 1308 & $>$ & 1348 & $>1366$ & Chethene & 74828 \\
\hline
\end{tabular}

It is clear from the table that initially, there were no changes. Minor variations occur after almost seventy years. It is important to draw attention to the copies from 1348, which are not identical. There is an original document from the Spiš Chapter House from 29th April 1348 deposited in the archive in Budapest under the number 74 809. Under the reference number 74811 there is a document from the same publisher from 16th May 1348. They were both copied from the same original from 1308 and despite that, presented variation occurred. This toponym will be in the database six times, because it has been preserved in six name forms, each having its own value. 
From the second category we can choose the case of the name of Iliašovce recorded in the document by Ladislaus IV from 1282, which we also know from the verified and unverified copy from the 18 th century.

\begin{tabular}{lccll} 
Form & Year & \multicolumn{1}{c}{ Year } & Entry & MNL OL \\
\hline A & 1282 & & Helyaszaza & DF 262 676 \\
E & 1282 & $>1766$ & Helyaszaza & DL 1 087 \\
F & 1282 & $>1701-1800$ & Helyashaza & DL 71 615
\end{tabular}

While the form A and E list identical toponym, the deviation is in the form F. Although only single grapheme is affected, this kind of change in the name of the settlement deprives us of the source value. The form Helyaszaza informs us about the ethnicity of the village owner as well. We also know from other sources, that Eliáš was the leader of the Spiš Saxon Province (Zsoldos 2011, 240). If we only knew the form Helyashaza (literally The House of Elias), we would have missed several connections, especially where a unique version of the village name is concerned (in the 13th century Iliašovce is mentioned as villa Vrsi-Medved’ova Ves \{Bear's Village\}, MNL OL DL 71611 : $1263>1787)$.

I have already mentioned a similar case in my extensive review The Hydronymy of the Slovak part of the Hornád Basin, focused mainly on material from Spiš (Labanc 2015, 242-243) concerning the name of the watercourse within the bounds of Kežmarok from 1269. We know the Bela IV Privilege from several preserved copies (B1, B2, C1 and C2) from the years 1399 - 1440. In these the same watercourse occurs in two name forms:

\begin{tabular}{|c|c|c|c|c|c|c|c|c|c|c|c|c|}
\hline Form & Year & & Year & & Year & & Year & & Year & Year & Entry & MNL OL DF \\
\hline B1 & 1269 & $>$ & 1270 & $>$ & 1399 & & 1399 & & & & $\begin{array}{l}\text { Byztriche } \\
\text { Byztrichepotoka }\end{array}$ & 281701 \\
\hline B2 & 1269 & $>$ & 1270 & $>$ & 1399 & $>$ & 1399 & $>$ & 1419 & & $\begin{array}{l}\text { Biztriche } \\
\text { Biztrichepotoka }\end{array}$ & 281717 \\
\hline $\mathrm{C} 1$ & 1269 & $>$ & 1270 & $>$ & 1399 & $>$ & 1399 & $>$ & 1434 & & $\begin{array}{l}\text { Vyzniche } \\
\text { Wyznichepotoka }\end{array}$ & 281723 \\
\hline $\mathrm{C} 2$ & 1269 & $>$ & 1270 & $>$ & 1399 & $>$ & 1399 & $>$ & 1434 & $>1440$ & $\begin{array}{l}\text { Wyzniche } \\
\text { Wyzniczepataka }\end{array}$ & 281737 \\
\hline
\end{tabular}

It is clear from the analysis of the name forms that the stream's name change (in this instance its position is not important) took place in the making of a verified copy of the Confirmation of Sigmund of Luxemburg from 1399 by the Spiš Chapter House in 1434. If we were not familiar with the forms earlier than $\mathrm{C} 1$ and $\mathrm{C} 2$, it would have affected the analyses of hydronymy or toponymic material in general. In these few examples, I have attempted to illustrate the need to present the name forms in individual documents as a sequence of dates. The search in the database will be separate for the issue date of the source itself and for the copy.

Type of source: This data follows on from the previous category. Diplomatic identifiers according to the central European style (defined by Monumenta Germaniae Historica, on diplomatic material of medieval Kingdom of Hungary applied by $\mathrm{CDSl}$ ) will be used to identify the types of preserved sources (A - autographum/originale; B - confirmatio; C - transsumptum medii aevi; $\mathrm{D}$ - apographum medii aevi; $\mathrm{E}$ - copia vidimata aevi recentioris; $\mathrm{F}$ - copia simplex aevi recentioris; $\mathrm{P}$ - protocollum autenticum; $\mathrm{R}$ - registrum medii aevi; $\mathrm{T}$ - edition typis impressa). 
Source repository location: The place of storage of the source will be specified in a standard way: archive - fund - reference number. When entering these values, the system will alert the editor to a match to prevent duplicate input of the toponyms from the same source.

Entry position in the source: This field plays its role particularly with larger manuscripts and multi-page books or scrolls, where retrospective search of the toponym would be highly time consuming. The entry position will be in the form: folio number - line number. The second number will indicate the line number in a particular folio. For paginated sources it will be possible to fill in the 'Page' field.

Author's name: Each entry will automatically be assigned the editor's name according to their login details. The focus and breadth of the database exceeds the possibilities of a single person, even if they devoted themselves to it for a long time and exclusively. We cannot even count on the creation of a larger team to fulfil its needs. The database requires time to establish itself not only amongst historians but also a wider academia. Depending on its usage, it will be suitable to develop it with additional investments - both personal and material.

In the initial phase, it will be used mostly by the narrow circle of editors, especially those covered by the grant. Crowdsourcing will play its role here, but given the scientific nature of the database, the crowd will not be utilized in a standard way. Perhaps a better word would be proficrowdsourcing, i.e. the use of a professional community, which is a potential target group of the database and might have an interest in its development. Involvement of such professionals has essentially three advantages:

- Each contributor, independently of others, can build their own reference register in their heuristic base, which will be accessible anytime and anywhere.

- Multi-contributor data aggregation and mutual sharing will bring acceleration of heuristics to individuals.

- Each entry is a separate record that can be quoted in academic works, thus creating an opportunity for authors to increase the number of citations, which is one of the main monitored scientometric data.

Bibliography and notes: Although the digital online database is an innovation for historical science, it must adhere to certain scientific standards. One of them is source referencing. Each entry will have space to include additional bibliography or sources that were used to locate the toponym. This space will not be sufficient for detailed evidence; therefore the portal should have a section for publishing more in-depth analyses. Of course, with regard to the scientometric criteria, it will be understandable if authors choose a conventional form of publication of their analyses in scientific journals. The 'Topographic/Toponymic blog' of the online database will provide outsourced articles with authors and editorial staff's consent.

Geographical localisation: The need for a consolidated fast-access tool for toponym localisation was one of the key inspirations for creating the online CTSM database.

Position of the toponym is marked in the active map as a circle with a specific radius for clear orientation. The lowest value is set to $1 \mathrm{~km}$, which creates a space with a surface of more than $3 \mathrm{~km}^{2}$. Size of the radius will vary depending on the abilities and possibilities of the editor to determine exact location of the toponym. The map with location marked by the circle is also accompanied by an indication of the eastern longitude and northern latitude. These values are generated automatically according to the location of the circle centre so that it will be possible to copy and use it in other map systems or geoinformation systems (GIS, e. g. via GeoJSON format). 
The search will be possible not only in the text part of the entry, but the search tool will be used also spatially. In lay terms, the toponym selection can be done by defining the space on the map, and the system will generate all the toponyms entered in the database that are located in the selected area (via own polygonal object created e. g. GeoJSON format).

The previous paragraphs outline the basic vision of the Slovakian medieval toponymy database format and functioning, which is the outcome of the VEGA No. 1/0162/16 project and launched in a test mode for the public in 2018. From the end of the year, the database is functional in terms of its ability for data input and its effective search (toponimica.sk).

\section{Linguists, onomasticians and other specialists as a target group of CTSM}

The idea of CTSM stems primarily from the need of an historian to quickly and reliably localise a toponym or select a group of places that could be identified with it. After developing the CTSM idea along with inspiration from the working methods of Prof. V. Sedlák, pedagogue of many years at the History Department of the Faculty of Arts at Trnava University, it may be stated that the database itself offers many possibilities for its utilisation in linguistic and onomastic research. Being a lay man in those subjects, I will only attempt to outline the areas of the CTSM database potential contribution to linguistics and onomastics.

\section{Historical Lexicology}

At the present stage the CTSM database focuses primarily on Slovakian territory. Provided that the database establishes itself and its existence fulfils its goals, it will be possible to extend the editorial team by adding members specialising in any geographical area. In that case, this type of database will be relevant to historical lexicology of the languages used in the Kingdom of Hungary. Its contribution to historical lexicology can be clearly illustrated by the example of the Slovak language. Thanks to the long-term research work of Slovak linguists, both professional and lay public has access to Historický slovník slovenského jazyka (HSSJ) \{Historical Dictionary of the Slovak Language\}. Selected sources were excerpted for its preparation, among which were manuscripts edited by Prof. R. Marsina in the Slovak Codex Diplomaticus (letters and manuscripts relevant to Slovakian territory up until 1260, CDSl I 1971 and CDS1 II 1987). All the sources that offer material for historical lexis research of the Slovak language using topographical names are in Latin. The CTSM database will contribute by expanding this group, since it will multiply the amount of material that can be used for such a purpose. Of course, the data will be entered regardless of the language, thus allowing deeper comparison.

For example, for the adjective královský (kralowa) \{royal\}, the HSSJ lists the earliest documented entry from 1473 from the municipal records of Žilina. During material collection for CTSM use, an earlier usage of this word from 1353 was found. It appears in the name of the road: antiqua semita Kralowastaraputh (MNL OL DF 262 672). This phrase, meaning Old Royal Road, at the same time provides even earlier evidence of the use of the substantive pút (puth) \{road\} (HSSJ, year 1575). Further examples can only be given schematically: 


\begin{tabular}{lllll} 
Word & \multicolumn{3}{c}{ HSSJ } & CTSM \\
\hline lán & old unit of field & & & \\
konopisko & measurement & 1358 & 1329 & laan \\
rakytie & hemp field & 1556 & 1437 & Na konopiskw \\
& willow stand & 1601 & 1255 & Rachathia
\end{tabular}

\section{Historical dialectology}

Its research is closely intertwined with historical lexis research and the principles of contribution of CTSM to its study are the same. Due to the systematic addition of data, the database can offer a wide sample of material, which could be specified chronologically and spatially. When there are sufficient numbers of entries documenting occurrence of a certain phenomenon, the linguist will be able to automatically create a map of its geographical occurrence.

A preview of the potential material for historical dialectological research:

\begin{tabular}{llllll}
$\begin{array}{l}\text { Entry } \\
\text { in the source }\end{array}$ & Year & Reconstruction & & $\begin{array}{l}\text { Grammatically } \\
\text { correct form }\end{array}$ & MNL OL \\
\hline Paulowe iavore & $1353>1354$ & Pavlove javore & Paul's maples & Pavlove javory & DF 262 672 \\
Na konopiskoch & 1437 & Na konopiskoch & Hemp fields & Na konopiskách & DL 63810 \\
fons Zthwczenka & 1437 & Studzenka & well & Studienka & DL 63 810
\end{tabular}

\section{Onomastics}

The CTSM database will have a particularly important contribution to the onomastics or toponomastics, as they cannot be fully developed solely by linguistic methods (Šmilauer 1966, 11). As history contributes to the development of toponomastics, so should toponomastics to history. Lack of comprehensive cooperation between these disciplines can lead to unnecessary inaccuracies on both sides and sometimes to the formulation of conclusions based on assumption rather than actual evidence.

A very interesting example worth mentioning is the abandoned medieval village of Krigov which once lay between today's villages of Pavlany and Olšavica in the Levoča district (FeketeNagy 1934, 161 $)^{11}$. Archaeologists dated the origin of this village back to the 13th century (Čaplovič - Javorský 1990, 82) and the onomasticians saw the origin of the name in a personal name (Goótšová - Chomová - Krško 2014, 227). However, after examination of the known written sources, both facts need to be reviewed. First and foremost, it is important to make a clear distinction between references to Krigov near Pavlany and to what today is known as Vojňany (Kežmarok district) in these sources. Both villages were located in Spiš County and they both appeared under a very similar name (Kyrig, Krig, Criga, Kryeg etc.) ${ }^{12}$ At this point, a minute analysis of their differentiation is not essential. Suffice it to say that the first direct mention of Krigov near Pavlany comes from the year 1343 and it appears in a document by the judge royal

${ }_{11}$ Its location resembles topographical name Krigov in the northern bounds of Pavlany. Object catalogue ZB GIS [cit. 2019-01-24]. Available on the Internet: https://zbgis.skgeodesy.sk/mkzbgis/?bm=zbgis\&z=1 $5 \& \mathrm{c}=20.72282,49.06939 \#$.

12 The origins of the names of both villages are in German word Krieg = Vojna \{war\}. Vojňany in Kežmarok district acquired its current name in 1948. 
Pavol documenting the agreement between the Spiš provost Ján and noblemen from Spiš Hrhov in the dispute about Krigov (SpP no. 67). This source mentions an alternative name for the village: possessio Kyryk seu alio nomine Iwanusy vocata. From the testament by provost Ján drawn up in 1348 we learn, that there was once a church dedicated to St. John the Baptist in the village (SASK scr $12 \mathrm{f} .1,2$ ). However, there is one more document relating to Krigov. It is a report by Jasov Convent of the investigations into atrocities committed by the residents of Vyšné Repaše. According to the testimony of the inhabitants from neighbouring Olšavica and ${ }^{\star}$ Margecianka, they launched an armed attack on the village of the Spiš provost known as Wyfolu (from Hun. New Village) and caused bodily harm to the people and losses to their herds of cattle (MNL OL DF 272 267).

The same dispute was resolved by the 1343 agreement. This means that in the case of Krigov, there are three names for the same place from the years 1342-1343, all with different sources:

- Wyfolu - from Hun. New Village - a reference to a newly established settlement,

- Kyryk - from Ger. Krieg = war, dispute - a reference to a conflict situation surrounding the beginnings of the settlement,

- Iwanusy - diminutive form of the name Ján - a reference to the patron saint of the local Church and de facto the provost as well, under whose period in office the village was founded. ${ }^{13}$

Later references to the village from 1355 and 1363 suggest that the name reflecting the conflict at the founding of the village (Crygo, SpP no. 82) has definitively established itself over the course of several years. If the toponyms from quoted documents were entered into the CTSM database, then a geographically defined selection combined with a location specification would yield the following results:

\begin{tabular}{|c|c|c|}
\hline Entry in the souce & Reconstructed Name & Year \\
\hline Wyfolu & Krigov & 1342 \\
\hline $\begin{array}{l}\text { possessio Kyryk seu alio nomine } \\
\text { Iwanusy vocata }\end{array}$ & Krigov & 1343 \\
\hline Iuanusy & Krigov & 1348 \\
\hline Crygo & Krigov & $1355>1363$ \\
\hline Crygo & Krigov & 1363 \\
\hline
\end{tabular}

Only onomasticians can decide how they will analyse and interpret a group of data selected this way. Their conclusions must then be reflected by historians and archaeologists. Again, examples of the CTSM online database benefits are presented here. Were such communication to take place by the established means currently used by historians and onomasticians, an enormous amount of time and effort would be required. If such discourse were to take place through the database entries (input by historians - interpretation by onomastician - use by historians and archaeologists), the time needed for such activity would dramatically shorten and the number of recipients would increase vastly. It is highly likely that with gradual growth and use of the database, people from both groups will eventually communicate scientific matters exclusively via the database. Of course, due to the database population method and the size of the group of historians potentially capable of effectively expanding it, it is assumed that a special group of regular contributors will be created. They will meet together, or meet its users, at certain time intervals which will promote

13 Analogy is provided by neighbouring Pavlany, which used to have church of St. Paul. One of the predecessors of the Spiš provost Ján was also Pavol \{Paul\} (1301 - 1315, Labanc 2011, 166-169). 
improvements and enhanced efficiency of the CTSM. This vision, however, seems distant, and the first step is to make the database itself operational.

\section{Standardisation of geographical names}

It is, in principle, an interdisciplinary application of theoretical knowledge from multiple disciplines. History plays its role by facilitating research into the development of the individual toponyms. Their exhaustive collection is helpful for linguistic and onomastic analysis and, ultimately, accelerates the standardisation itself. Due to the numbers of already standardised names from the Basic maps of SR level of detail 1: 50000 and 1: 10000 (between 1974-1994 there were 68314 names, Horňanský 2011,216) building of the CTSM has potentially an important role in standardisation from a more detailed scale, as the search for historical forms of the topographical names in the lower levels is much more challenging.

\section{Conclusion}

This theoretically outlined idea of CTSM is the result of several impulses. The core one has been an everyday need for a fast and effective tool for identification and localisation of places found in written sources. An historian specialising in the Middle Ages (of Kingdom of Hungary) is regularly confronted during this task with the absence of a systematic and methodologically unified handbook. These ideas were combined with inspiration from work by Prof. V. Sedlák, who spent his entire professional life researching toponyms. Last but not least, it is the works of linguists and onomasticians mapping the hydronyms of watercourses, water bodies and springs (e. g. Hydronymia Slovaciae Project as part of the Hydronymia Europaea project, Krško 2005). However, they are met with insufficient support from historians (mainly for 15th and 16th century).

Within these parameters, the idea of a digital database with the working title Corpus Toponymicum Slovaciae Medievalis is formed. It will be available online and gradually populated by historians through their study of the original sources. This will create not only a so far nonexistent localisation handbook, but moreover, will offer the benefits of search in digital databases. In addition to the primary reason of its existence, however, we have to assume its usage in other disciplines. The few examples mentioned above illustrate its potential contribution to historic lexicology, dialectology, onomastics or standardisation. Preliminary research suggests that in the future that list will be longer. ${ }^{14}$ In addition, it should be emphasized that this kind of database allows for any spatial and chronological expansion, ${ }^{15}$ limited only by the amount of space available on servers. ${ }^{16}$

14 E. g. archeology (Saarikivi - Lavento 2012, 179 and 201), spreading of ethnic groups (Marek 2006), geographical horizon of medieval people (Verešová 2008; Verešová 2011; Malinovská 2013), reconstruction of medieval road network (Ivanič 2011, 20-23), research of the church topography and cult-of-saints geography (Slivka 2013, 135-140), etc.

15 There are strong reasons to populate the CTSM database with data from specific early-modern sources, e. g. canonical visitations (Lopatková 2014, 29), Mathias Bel's Notitia (Rácová 2017, 194-197) or urbaria (Urbáre I - II 1959). The question of populating database by place names in epigraphical sources (e. g. Čovan 2016, Glejtek 2013) should be discussed in the forthcoming papers.

16 The article is a part of project VEGA No. 1/0162/16. 


\section{REFERENCES}

Beláková, Mária. 2014. Hydronymia severnej časti povodia Malého Dunaja. Trnava.

Beňko, Ján. 1985. Osídlenie severného Slovenska. Košice.

Beňko, Ján. 1996. Starý Turiec. Martin.

Čaplovič, Dušan - Javorský, František. 1990. Najnovšie poznatky o vývoji stredovekého dedinského domu na Spiši. In Nové obzory 31, 69-122.

CDSl I. 1971. Marsina, Richard (ed.). Codex diplomaticus et epistolaris Slovaciae I. Bratislavae.

CDSl II. 1987. Marsina, Richard (ed.). Codex diplomaticus et epistolaris Slovaciae II. Bratislavae. Chaloupecký, Václav. 1923. Staré Slovensko. Bratislava.

Csánki, Dezső - Fekete-Nagy, Antal. 1890 - 1941. Magyarország történelmi földrajza a Hunyadiak korában I - V. Budapest. http://www.arcanum.hu/hu/online-kiadvanyok/ Csanki-csanki-dezso-magyarorszag-tortenelmi-foldrajza-a-hunyadiak-koraban-1/.

Čovan, Miroslav. 2016. Historické nápisy zo Šariša do roku 1650. Martin.

Fekete-Nagy, Antal. 1934. A Szepesség területi és társadalmi kialakulása. Budapest.

Glejtek, Miroslav. 2013. Stredoveké cirkevná pečat'. Prameň krestanskej ikonografie. Hradec Králové.

Goótšová, Andrea - Chomová, Alexandra - Krško, Jaromír. 2014. Hydronymia slovenskej časti povodia Hornádu. Banská Bystrica.

Györffy, György. 1963 - 1998. Az Árpád-kori Magyarország történeti földrajza I - IV. Budapest.

Házi, Jenő. 2000. Pozsony vármegye középkori földrajza. Pozsony.

Hladký, Juraj. 2011. Hydronymia povodia Dudváhu. Trnava.

Horňanský, Imrich. 2011. Poznámky k štandardizácii geografických názvov. In Slovenská reč 76/4, 214-222.

HSSJ. 1991 - 2008. Historický slovník slovenského jazyka I - VII. Bratislava.

Hudáček, Pavol. 2016. Castrum Salis. Severné pohraničie Uhorska okolo roku 1000. Bratislava.

Húščava, Alexander. 1930. Kolonizácia Liptova do konca XIV. storočia. Bratislava.

Ivanič, Peter. 2011. Stredoveká cestná siet' ma Pohroní a Poiplí. Nitra.

Kavuljak, Andrej. 1955. Historický miestopis Oravy. Bratislava.

Krško, Jaromír. 2005. Spracovanie hydronymie Slovenska. Metodické pokyny na spracúvanie projektov Hydronymie Slovaciae. Banská Bystrica.

Labanc, Peter. 2011. Spišskí prepošti do roku 1405. Kraków - Trnava.

Labanc, Peter. 2013. Vývoj šlachty na Spiši do začiatku 14. storočia. Kraków - Trnava.

Labanc, Peter. 2015. Niekolko poznámok a postrehov k hydronymii Hornádu na Spiši. In Z minulosti Spiša 23, 231-244.

Lopatková, Zuzana. 2014. Kanonické vizitácie severozápadnej časti Podhorského dekanátu v 2. polovici 16. storočia a v 17. storočí. Trnava - Kraków.

Majtán, Milan - Rymut, Kazimierz. 2006. Hydronymia povodia Oravy. Bratislava.

Maliniak, Pavol. 2009. Človek a krajina Zvolenskej kotliny v stredoveku. Banská Bystrica.

Malinovská, Nora 2013. Geographical concepts of Sclavinia in historical sources from the sixth to the fourteenth century, with an emphasis on the Moravian-Pannonian and South Slavic traditions. In Homza, Martin - Budak, Neven (eds.). Slovakia and Croatia. Historical parallels and connections (until 1780). Bratislava - Zagreb, 60-65.

Mályusz, Elemér. 1922. Turóc megye kialakulása. Budapest.

Marek, Miloš. 2006. Cudzie etniká na stredovekom Slovensku. Martin.

Marek, Miloš. 2010. Fontes rerum Slovacarum II. Archivum Familiae Motešický. Stredoveké listiny z archívu rodiny Motešickovcov. Kraków - Trnava. 
Marek, Miloš. 2013. Fontes rerum Slovacarum III. Archivum Familiae Majténi. Stredoveké dejiny rodiny Majténiovcov a listiny z jej archívu. Kraków - Trnava.

Marsina, Richard. 1957. O potrebe a zásadách vydávania Slovenského diplomatára. In Historický časopis 5/3, 297-314.

MNL OL DF = Magyar Nemzeti Levéltár, Országos Levéltár, Budapest, Diplomatikai Levéltár.

MNL OL DL = Magyar Nemzeti Levéltár, Országos Levéltár, Budapest, Diplomatikai Fényképgyüjtemény.

Mrekaj, Michal. 2012. Historicko-geografická charakteristika Oravskej župy do začiatku 17. storočia (Formovanie kultúrnej krajiny). Unpublished dissertation. University of Trnava. Trnava.

MVH I/1. 1887. Monumenta Vaticana Hungariae. Series I. Tomus I. Rationes collectorum ponitficorum in Hungaria 1281 - 1375. Budapest.

MVSl I. 2008. Sedlák, Vincentius (ed.). Monumenta Vaticana Slovaciae I. Rationes collectorum ponitficiorum in annis 1332 - 1337. Trnavae - Romae.

Ördög, Ferenc. 2002. Helynévmutató Csánki Dezső történelmi földrajzához. Budapest.

Polla, Belo. 1962. Stredoveká zaniknutá osada na Spiši (Zalužany). Bratislava.

Rábik, Vladimír. 2006. Nemecké osídlenie na území východného Slovenska v stredoveku (Šarišská župa a slovenské časti žúp Abovskej, Zemplínskej a Užskej). Bratislava.

Rácová, Katarína. 2017. Vodné toky Nitrianskej stolice v Belových vedomostiach. In Studia Historica Nitriensia 21/1, 191-197.

Rácz, György. 2010. Collectio Diplomatica Hungarica. Medieval Hungary online: The online portal of the National Archives of Hungary on medieval charters. In Archiv für Diplomatik Schriftgeschichte Siegel- und Wappenkunde 56, 423-444.

Rapant, Daniel. 1934. Starý Liptov. Kus polemiky s prof. V. Chaloupeckým. Bratislava.

RDSl I. 1980. Sedlák, Vincentius (ed.). Regesta diplomatica nec non epistolaria Slovaciae I. Bratislavae.

RDSl II. 1987. Sedlák, Vincentius (ed.). Regesta diplomatica nec non epistolaria Slovaciae II. Bratislavae.

Saarikivi, Janne - Lavento, Mika. 2012. Linguistics and Archaeology: A Critical View of an Interdisciplinary Approach with Reference to the Prehistory of Northern Scandinavia. In Damm, Charlotte - Saarikivi, Janne (eds.). Networks, Interaction and Emerging Identities in Fennoscandia and Beyond: Papers from the conference held in Tromsø, Norway, October 13 - 16 2009. Helsinki, 177-217.

SASK = Štátny archív v Prešove, Spišský archív v Levoči, fond Súkromný archív Spišskej kapituly.

Sedlák, Vincent. 2003. Nevšedné životné jubileum významného vedeckého pracovníka a pedagóga. In Šimončič, Jozef (ed.). Studia historica Tyrnaviensia III. K životnému jubileu Dr. h. c. Univ. prof. PhDr. Richarda Marsinu, DrSc. Trnava, 9-12.

Slivka, Michal. 2010. Historiografia spišskej historickej antropológie stredoveku. In Kultúrne dejiny $1 / 1,44-100$.

Slivka, Michal. 2011. Titulus ecclesiae v sídelnej, právnej a sociálnej štruktúre stredovekého Spiša. In Slivka, Michal. Pohlady do stredovekých dejín Slovenska. Martin, 135-140.

Šmilauer, Vladimír. 1932. Vodopis starého Slovenska. Praha - Bratislava.

Šmilauer, Vladimír. 1966. Úvod do toponomastiky. Praha.

$\mathrm{SpP}=$ Štátny archív v Prešove, Spišský archív v Levoči, fond Spišské prepoštstvo.

Števík, Miroslav. 2006. Stredoveká zaniknutá osada na Spiši (Zalužany)? In Števík, Miroslav (ed.). K dejinám Podolínca a novovekého Spiša. Stará Lubovňa, 103-108. 
Števík, Miroslav. 2011. Krátke poznámky k dejinám Spišskej kapituly a osady Štefkovce na základe rozboru metácie z roku 1274. In Števík, Miroslav (ed.). Spiš v 12. a 13. storočí. Stará Lubovňa, 98-103.

Tibenský, Martin. 2011. Červenokamenské panstvo v stredoveku. Kraków - Trnava.

Uličný, Ferdinand. 1983. Dejiny osídlenia Liptova do konca 16. storočia (1. čast'). In Liptov 7, 39-90.

Uličný, Ferdinand. 1985. Dejiny osídlenia Liptova do konca 16. storočia (2. čast'). In Liptov 8, 133-208.

Uličný, Ferdinand. 1987. Dejiny osídlenia Liptova do konca 16. storočia (3. čast'). In Liptov 9, 61-149.

Uličný, Ferdinand. 1990. Dejiny osídlenia Šariša. Košice.

Uličný, Ferdinand. 1995. Dejiny osídlenia Užskej župy. Prešov.

Uličný, Ferdinand. 2001. Dejiny osídlenia Zemplínskej župy. Michalovce.

Urbáre I - II. 1959. Kušík, Michal - Marsina, Richard (eds.). Urbáre feudálnych panstiev na Slovensku I - II. Bratislava.

Varsik, Branislav. 1964 - 1977. Osídlenie Košickej kotliny I - III. Bratislava.

Verešová, Nora. 2008. Vývoj chápania geografického termínu Sklavínia v historických prameňoch 6. - 14. storočia. In Historický zborník 18/1,124-143.

Verešová, Nora. 2011. Povest' vremennych let a jej koncepcia Slovienskoj zemli. In Historia Nova II/1. Štúdie k jubileu Pavla Jozefa Šafárika. Bratislava, 12-20.

VSO I-III. 1977 - 1978. Vlastivedný slovník obcí na Slovensku I - III. Bratislava.

Závodný, Andrej. 2012. Hydronymia slovenskej časti povodia Moravy. Trnava.

ZsO XII. 2013. C. Tóth, Norbert - Lakatos, Bálint (eds.). Zsigmondkori oklevéltár XII. (1425).

Budapest.

Zsoldos, Attila. 2011. Magyarország világi archontológiája 1000 - 1301. Budapest.

SUMMARY: CORPUS TOPONYMICUM SLOVACIAE MEDIEVALIS (CTSM) ON-LINEDATABASE OF MEDIEVAL TOPONYMICMATERIAL ANDITS APPLICATION IN ONAMASTIC AND LINGUISTIC RESEARCH. The main goal of the current paper was to present Corpus Toponymicum Slovaciae Medievalis (CTSM) - the on-line database of medieval toponymy from present day Slovakia. This paper has been divided into three parts. The first part deals with several reasons for creation of the CTSM database. An important impetus was the absence of the uniform tool which would cover the whole terrain of present-day Slovakia as a part of medieval Hungarian Kingdom. The second part is concerned with the form of the database table, or, better to say, with the types of data that should populate the database. As a result of three years of testing (2016-2018) three groups of data were identified: automatically populated (ID; name of record's author); mandatory data (transliterated toponym, today's name, location type, source issue date, type of source, source repository location, entry position in the source, geographical localisation with radius of indeterminacy) and optional data (bibliography and notes). The last section presents the potential applications of the database in various research fields, focusing on the four key areas: historical lexicology, historical dialectology, onomastics and standardisation of geographical names. Finally, the conclusion gives a brief summary of the paper and suggests that in the future list of applications will be longer. 
Peter Labanc

Mgr. Peter Labanc, PhD.

University of Trnava

Faculty of Philosophy and Arts

History Department

Hornopotočná 23

91843 Trnava

Slovakia

peter.labanc@truni.sk 